\title{
The Impacts of Cement Dust Deposits on Soil Available Micronutrients
}

\author{
Buba M. Wufem \\ Chemistry Department \\ Plateau State University \\ Nigeria Yola, Nigeria
}

\author{
Nangbes, J. Gungsat \\ Chemistry Department \\ Plateau State University \\ Bokkos, Nigeria
}

\author{
A. Q. Ibrahim \\ Chemistry Department \\ Police Academy \\ Nigeria Wudil, \\ Kano Nigeria
}

\author{
Humphrey M. Maina \\ Chemistry Department \\ Federal University of Technology \\ Bokkos, Nigeria
}

\begin{abstract}
The impact of cement dust deposits on soils micronutrient around Ashaka cement factory, Nigeria was evaluated by determining available micronutrient elements in 68 soil samples and some crop plant stalks using acid extraction and atomic absorption spectrophotometric methods. Soil samples collected in a radius of $6 \mathrm{Km}$ from a $0-30 \mathrm{~cm}$ depth and analysed indicated mean concentrations of $215.30 \mathrm{gKg}^{-1} \mathrm{Fe}, 7.96 \mathrm{gKg}^{-1} \mathrm{Zn}, 0.33 \mathrm{gKg}^{-1} \mathrm{Cu}, 80.79 \mathrm{gKg}^{-1} \mathrm{Mn}, 2.05 \mathrm{gKg}^{-1} \mathrm{Ni}$, and $26.91 \mathrm{gKg}^{-1} \mathrm{Co}$. The concentration of each element in the soil varies in a decreasing order with increasing distance away from the cement factory and generally occurring above background levels $(\mathrm{Zn}, \mathrm{Mn}, \mathrm{Ni})$. The metals in the crop plants were higher than normal levels with sorghum concentrating more metals than millet, suggesting a reflection of the soil metal concentrations and this might be due to the presence of available mobile elements and the slightly acidic nature of the soil outside the factory.
\end{abstract}

Keywords: Micronutrients, cement dust, Contamination, Crops

\section{INTRODUCTION}

Dust has been attributed to be one of the major causes of pollution in the environment. It is emitted into the atmosphere from natural and anthropogenic sources such as volcanic eruption, dust storms, road traffic, industrial processes, etc and soil serves as a major sink for its deposition $[1,2]$. Dust consists of solid matter in such a fine state of subdivision that the particles are small enough to be raised and carried by wind [3]. As a result of its fine particle size it travels over long distances and the total suspended particulate matter in the atmosphere is thus increased. Often industrial processes produce particulate emissions whose depositions may be accompanied with potential impacts caused to human and animal health, vegetations and soil [2]. The emissions of particulate matter to air by cement industries have constituted a major problem in most third world countries mostly due to economic constraints [4]. Recently, efforts have been put in place in most cement industries to suppress dust emission; nevertheless, past activities of cement industries have left farmlands in bad conditions. The main environmental pollutants generated by the company are dust and noise and these could cause dust laden air, cracking of walls of structures as well as soil and water polluted by dust to an extent that farming may be unprofitable [5]. The effects of cement dust on crop seedling emergence, concentration of hexoses in scot spine, radial growth of spruce stands have been documented $[6,7,8]$. The dust was reported to reduce the uptake of heavy metals in sludge soil by corn [9] (. Cement dust may contain heavy metals and other chemical compounds that may include $\mathrm{F}, \mathrm{Mg}, \mathrm{Pb}, \mathrm{Zn}, \mathrm{Cu}, \mathrm{Be}, \mathrm{H}_{2} \mathrm{SO}_{4}$, and $\mathrm{HCl}[10,11,12]$. Metals are considered very important to man and plants but some could be highly toxic and can be a source of pollution. Recently, $\mathrm{Cu}, \mathrm{Ni}$, and $\mathrm{Zn}$ were listed among metals that cause pollution [13] and these may pose risk and hazards to humans and ecosystem through ingestion or contact, food chain, drinking of contaminated ground or surface water, etc. Micronutrient elements ( $\mathrm{Fe}, \mathrm{Cu}, \mathrm{Zn}, \mathrm{Mo}, \mathrm{Mn}, \mathrm{Co}$ ) are made up of mostly heavy metals of the transition groups that are essential to man, animal and plant nutrition. Heavy metals occur naturally in the soil environment from pedogenic processes of weathering of parent materials at levels that are regarded as trace i.e < $1000 \mathrm{mgkg}^{-1}$ and is rarely toxic $[14,15]$. Due to the disturbance and nature's occurring geochemical cycle of metals by man most soils accumulate heavy metals above background levels high enough to cause risks to human health, plants, animals, ecosystems, or other media [16]. $\mathrm{Fe}, \mathrm{Cu}, \mathrm{Zn}, \mathrm{Co}$, and $\mathrm{Mn}$ are required for normal growth and metabolism of plants but may be toxic at high concentrations $[17,18]$. Heavy metals uptake by plants and successive accumulation in human tissues and biomagnifications through food chain causes both human health and environmental concerns [19]. The absorption of heavy metals by plant roots is one of the main ways they enter the food chain and their accumulation in plant tissues depends upon temperature, moisture, organic matter, $\mathrm{pH}$, nutrient availability and plant species [20,21,22]. Moreover the efficiency of different plants in absorbing heavy metals is evaluated by either plant uptake or soil to plant transfer factors 
of the metals [21]. The extent of effects of toxic metals on biological and biochemical properties of soil can be influenced by organic matter, clay contents and $\mathrm{pH}$ [23], nevertheless, toxic metals in the soil can severely inhibit the biodegradation of organic contaminants [24]. This work was aimed at assessing the influence of cement dust deposits on plant available Iron, Zinc, Manganese, copper, Nickel and Cobalt in cultivated soils around a cement factory.

\section{EXPERIMENTALS}

\subsection{The study Area}

Ashaka Cement Company was established in 1976 with an installed capacity of 500,000 MT [25] to meet the needs of construction works in the Northeastern part of Nigeria. It lies between longitude $10^{\circ} 45^{\prime} \mathrm{N}$ and $11^{\circ} 00^{\prime} \mathrm{N}$ and latitude $11^{\circ}$ $15^{\prime} \mathrm{E}$ and $11^{\circ} 30^{\prime} \mathrm{E}$ and is located in the Northern part of Gombe State, Nigeria. The area is cultivated with maize, millet, sorghum beans and groundnut being the most widely planted. Prior to now, a significant amount of dust from the factory was deposited on farmlands, homes and water bodies including the River Gongola that cuts across the area.

\subsection{Sample Collection}

Soil sample was collected from cultivated farmlands around the cement factory covering an area of about $112 \mathrm{Km}^{2}$ starting from the factory fence to $6 \mathrm{~km}$ radius. Soils from $0-30 \mathrm{~cm}$ depths were sampled at every $2 \mathrm{Km}$ distance. Stalks and leaves of millet and Sorghum were also collected at every soil sampled points.

\subsection{Sample Treatment}

Soil and plant samples were dried at $105^{\circ} \mathrm{C}$ in an oven until constant weight was obtained. Soil sample was ground and sieved through a $2 \mathrm{~mm}$ screen plastic sieve. The plant sample was washed before drying at $105^{\circ} \mathrm{C}$ and ground in a ceramic mortar before being stored in plastic bottles.

\subsection{Reagents and Chemicals}

Table 1:

Mean Available Concentration of Micronutrient Metals in Cultivated Soils $(0-30 \mathrm{~cm})$ around Ashaka Cement Factory
All analyses were performed with Analar grade chemicals and distilled water through out, unless otherwise stated.

\section{5 pH Determination}

$\mathrm{pH}$ of soil was determined using Philips $\mathrm{pH}$-meter, model PW 9418 after shaking $5 \mathrm{~g}$ of the soil with $5 \mathrm{~cm}^{3}$ of water.

\subsection{Metal Extraction}

A mixture of $1 \mathrm{~g}$ soil and $10 \mathrm{~cm}^{3}$ of $0.1 \mathrm{M} \mathrm{HCl}$ was shaken for $1 \mathrm{hr}$ on a mechanical shaker and the supernatant solution filtered using whatman filter paper No. 44 into a $100 \mathrm{~cm}^{3}$ volumetric flask. (It was repeated twice). The filtrate was made up to $100 \mathrm{~cm}^{3}$ mark with distilled water.

\subsection{Digestion of plant crops}

Ground crop leaves and stalks were weighed $(0.5 \mathrm{~g})$ into a digestion tube and $100 \mathrm{~cm}^{3}$ of mixture of concentrated nitric and perchloric acid $(2: 1 \mathrm{v} / \mathrm{v})$ was added. The tube was heated at $150^{\circ} \mathrm{C}$ in a digestion block and later increased to $230^{\circ} \mathrm{C}$ until the solution became clear. The temperature was reduced to $150^{\circ} \mathrm{C}$ and $10 \mathrm{~cm}^{3}$ hydrochloric acid was added and heated again for 30 minute before cooling. The content was then transferred quantitatively into a $100 \mathrm{~cm}^{3}$ volumetric flask and made to mark with water before filtering into plastic bottles. (It was repeated twice).

\subsection{Metal Analysis}

The filtrate obtained was analysed for $\mathrm{Zn}, \mathrm{Cu}, \mathrm{Ni}, \mathrm{Mn}, \mathrm{Fe}$ and Co using a Buck Scientific Atomic Absorption Spectrophotometer model 210 VGP. Air-Acetylene (8:6) flame and hollow cathode lamps for the respective elements were used at their various wavelengths. Calibration standards were obtained by preparing $100 \mu \mathrm{g} / \mathrm{cm}^{3}$ stock solution of the nitrate salts of the metals and the stock solution diluted to obtain working standards. Triplicate analyses were carried out for each sample.

\section{RESULTS AND DISCUSSION}

The overall mean available metals in cultivated soils as acid extractable metals are shown in Table 1 for $0-30 \mathrm{~cm}$.

\begin{tabular}{lcccc}
\multicolumn{5}{c}{ Factory } \\
Metals & No. of Samples & $(\mathrm{g} / \mathrm{Kg})$ & $\begin{array}{c}\text { Concentration } \\
\text { Deviation }\end{array}$ & $\begin{array}{c}\text { Standard Range } \\
(\mathrm{g} / \mathrm{Kg})\end{array}$ \\
\hline $\mathrm{Fe}$ & 62 & 215.30 & 228.05 & $2-960.10$ \\
$\mathrm{Zn}$ & 62 & 7.96 & 5.71 & $0.00-27.76$ \\
$\mathrm{Cu}$ & 62 & 0.33 & 0.18 & $0.09-0.95$ \\
$\mathrm{Mn}$ & 62 & 80.79 & 32.2 & $1.40-311.43$ \\
$\mathrm{Ni}$ & 62 & 2.05 & 3.31 & $0.00-33.95$ \\
$\mathrm{Co}$ & 62 & 26.91 & 24.33 & $0.60-100.72$ \\
\hline
\end{tabular}


The mean available acid extractable micronutrient metal concentrations in cultivated soils with respect to distance from factory are shown in Table 2, while the overall mean micronutrient metal concentrations in plant crops commonly grown around the cement factory are provided in Table 3 . The concentration factors for the various micronutrient metals for millet and Sorghum were obtained by dividing the plant metal concentrations by the soil metal concentrations and their results are shown in Tables 4 and 5 respectively.

Table 2:

Mean Micronutrient Metal Concentrations $(\mathrm{g} / \mathrm{Kg})$ and $\mathrm{pH}$ in Cultivated Soils $(0-30 \mathrm{~cm})$ at Distances from Factory

\begin{tabular}{llccccccc}
\hline $\begin{array}{l}\text { Distance } \\
(\mathrm{Km})\end{array}$ & $\mathrm{pH}$ & $\mathrm{Fe}$ & $\mathrm{Zn}$ & & $\mathrm{Cu}$ & $\mathrm{Mn}$ & $\mathrm{Ni}$ & $\mathrm{Co}$ \\
\hline 0 & 7.57 & 316.5 & 9.86 & 0.40 & 108.12 & 3.35 & 32.02 \\
2 & 6.76 & 272.9 & 8.59 & 0.32 & 65.02 & 1.82 & 30.36 & \\
4 & 6.38 & 116.8 & 7.50 & 0.30 & 45.56 & 1.51 & 26.16 & \\
6 & 6.27 & 95.35 & 5.05 & 0.29 & 52.53 & 1.13 & 13.84 & \\
\hline
\end{tabular}

Table 3: $\quad$ Average Concentrations of Micronutrient Metals $\left(\mathrm{g} / \mathrm{kg}^{-1}\right)$ in Millet and Sorghum at Factory

\begin{tabular}{|c|c|c|c|c|c|}
\hline \multirow[t]{2}{*}{ Metals } & \multicolumn{3}{|l|}{ Millet } & \multicolumn{2}{|c|}{ Sorghum } \\
\hline & Conc & Range & Conc & & Range \\
\hline $\mathrm{Fe}$ & 44.38 & $15.94-149.31$ & 64.35 & & $16.63-149.31$ \\
\hline $\mathrm{Zn}$ & 4.11 & $1.79-7.97$ & & 10.10 & $2.17-146.83$ \\
\hline $\mathrm{Cu}$ & 35.00 & $0.09-56.0$ & & 32.50 & $0.15-49.3$ \\
\hline $\mathrm{Mn}$ & 667.00 & $48.00-1497.9$ & 190.5 & & $34.00-363.46$ \\
\hline $\mathrm{Ni}$ & 5.30 & $1.98-11.95$ & & 6.05 & $1.89-9.90$ \\
\hline Co & 11.34 & $2.01-79.86$ & & 50.90 & $2.00-139.61$ \\
\hline
\end{tabular}

Table 4: Mean Concentration Factors for Micronutrient Metals in Soil and Millet with Distance.

\begin{tabular}{lcccccccc}
\hline $\begin{array}{l}\text { Distance } \\
(\mathrm{Km})\end{array}$ & $\mathrm{pH}$ & $\mathrm{Fe}$ & $\mathrm{Zn}$ & $\begin{array}{c}\text { Metals } \\
\mathrm{Cu}\end{array}$ & $\mathrm{Mn}$ & $\mathrm{Ni}$ & Co \\
\hline & & & & & & & & \\
0 & 7.57 & 0.191 & 0.425 & 0.125 & 0.032 & 2.069 & 0.288 & \\
2 & 6.76 & 0.128 & 0.430 & 0.094 & 0.097 & 2.918 & 0.298 & \\
4 & 6.38 & 0.299 & 0.589 & 0.100 & 0.059 & 3.027 & 0.288 & \\
6 & 6.27 & 0.424 & 1.346 & 0.103 & 0.144 & 6.708 & 0.465 & \\
\hline
\end{tabular}

Table 5: Mean Concentration Factors for Micronutrient Metals in Soil and Sorghum with Distance 
International Journal of Science and Engineering Applications

Volume 3 Issue 4, 2014, ISSN-2319-7560 (Online)

\begin{tabular}{|c|c|c|c|c|c|c|c|c|}
\hline $\begin{array}{l}\text { Distance } \\
(\mathrm{Km})\end{array}$ & $\mathrm{pH}$ & $\mathrm{Fe}$ & $\mathrm{Zn}$ & $\begin{array}{c}\text { Metals } \\
\mathrm{Cu}\end{array}$ & & Mn & $\mathrm{Ni}$ & $\mathrm{Co}$ \\
\hline 0 & 7.57 & 0.207 & 20.892 & 0.100 & 0.191 & 3.701 & 0.191 & \\
\hline 2 & 6.76 & 0.215 & 19.569 & 0.094 & 0.181 & 5.319 & 0.137 & \\
\hline 4 & 6.38 & 0.752 & 34.800 & 0.133 & 0.395 & 11.371 & & 0.201 \\
\hline 6 & 6.27 & 0.452 & 26.000 & 0.069 & 0.196 & 9.354 & 0.321 & \\
\hline
\end{tabular}

It has been suggested [26] that concentrations of plant total metals do not adequately reflect the degree of absorption by plants. The extractable metal contents, a more direct indication of the availability of the absorbed metals and the possibility of re-mobilization have been reported [27] not to be a true mirror of plant available metals. Trace element uptake by roots are influenced by both soil and plant factors such as source and chemical form of elements in soil, $\mathrm{pH}$, organic matter, plant species, etc. [28]. Interaction between elements occurring at the root surface and within the plant can affect uptake, as well as translocation and toxicity [29].

\subsection{Iron in Crop Plants}

The mean iron contents of millet and Sorghum are $44.38 \mathrm{gkg}^{-1}$ and $64.35 \mathrm{gkg}^{-1}$ with concentrations varying over wide ranges, $15.94-149.31 \mathrm{gkg}^{-1}$ and $16.63-149.31 \mathrm{gkg}^{-1}$ respectively (Table 3 ). These values are higher than the normal composition of $\mathrm{Fe} 150 \mathrm{\mu gg}^{-1}$ ) in plants [30]. These agree with many findings as reported by Voutsa et al. [28] that elevated levels of metals in soils lead to increased plant uptake. Concentration factors for iron from soil to millet and sorghum are given in tables 4 and 5. The factors for the millet and Sorghum for iron are not significantly different and this suggests similar soil factors that control iron absorption in both millet and sorghum crop plants. However, the high absorption of iron at the $4 \mathrm{Km}$ distance must have been due to the long iron residence in solution form as a result of the river that cuts through the eastern part of the study area.

\subsection{Zinc in Crop Plants}

The mean zinc concentration in millet and Sorghum are $4.11 \mathrm{gkg}^{-1}$ and $10.10 \mathrm{gkg}^{-1}$ respectively (Table 3 ). These plant crops have wide distribution of Zinc ranging from $1.79-$ $7.97 \mathrm{gkg}^{-1}$ and $2.17-146.83 \mathrm{gkg}^{-1}$ for millet and sorghum respectively. The zinc levels in the crops appear higher than the normal zinc levels in plants [30]. Sorghum showed higher performance for zinc absorption than millet. The zinc levels are too high to be of very much concern as it posed serious potential hazard to the environment. The high level agrees with the report by other researchers that plants growing in a polluted environment can accumulate trace elements at high concentrations that could cause serious risk to human health when plant based food stuff are consumed [31,32,33,34]. Zinc has been reported to be more phytotoxic than other commonly occurring metals with serious implications for human health [35, 36, 37, 38]. Larsen et al. and Harrison and Chirgawi [37, 38 ] have shown a relationship between atmospheric elements deposition and elevated element concentrations in plants and top soils especially in cities and in the vicinity of emitting factories. Atmospheric elements are deposited on plant surfaces by rain and dust with the airborne sub-micro particles filtered out on plant surfaces. This constitutes a substantial, but unknown, contribution to the atmospheric supply and the large- scale sustained exposure of soil to both wet and dry deposition of trace elements constituting the indirect effect of air pollutants through the soil [28].

\subsection{Copper in Crop Plants}

Millet and Sorghum mean copper concentrations are $35.00 \mathrm{gkg}$ and $32.50 \mathrm{gkg}^{-1}$ with a range of $0.09-56.00$ and 0.15 $-49.30 \mathrm{gkg}^{-1}$ respectively (Table 3 ). These levels are higher than the normal mean plant concentrations of $10 \mathrm{\mu gg}^{-1}$ [30]. The concentration factors (Tables 4 and 5) indicated the extractable metals to be less absorbed even though it is supposed to represent an estimate of the plant available levels. However, it has been found that soil metal content does not necessarily mirror the plant metal bioavailability [27]. Copper has been associated with important potential pollutants [39]. Its mobility seems not to be influenced by $\mathrm{pH}$, from soil to plants. The relatively high copper concentration of crop plants suggests that the soils upon which they were grown were contaminated. This spelled danger for the community residing in the vicinity of the factory.

\subsection{Manganese in Crop Plants}

Manganese concentrations in Millet and Sorghum vary over a wide range, $48.00-1497.9 \mathrm{gkg}^{-1}$ and 34.00 $363.46 \mathrm{~g} / \mathrm{kg}$ with mean concentration of $667.00 \mathrm{gkg}^{-1}$ and $190.50 \mathrm{gkg}^{-1}$ respectively (Table 3 ). The absorption of Manganese by sorghum is less than that by Millet. Normal plant manganese has been put at $200 \mathrm{\mu gg}^{-1}$ [30], which is far less than the Manganese levels found at minimum concentrations in plants. The high absorption reflects the level of contamination of the soils and there seems to be no clear pattern in the absorption of the metals in both plants with changing distances (Tables 4 and 5).

\subsection{Nickel in Crop Plants}

Millet and Sorghum were found to contain mean concentration of nickel of $5.30 \mathrm{gkg}^{-1}$ and $6.05 \mathrm{gkg}^{-1}$ respectively. The distribution of nickel in the plant crops analysed ranges from $1.98-11.95 \mathrm{gkg}^{-1}$ and $1.89-9.90 \mathrm{gkg}^{-1}$ for millet and sorghum respectively (Table 3 ). The average nickel in plants is $1.5{\mu g g^{-1}}^{-130]}$, suggesting nickel in the plant crops studied to be higher than normal. The concentration factors (Tables 4 and 5) increase with distance. The factors are greater than one at each sample point, which is an indication of high mobility from the soil to the plant crops. This means that millet and sorghum grown on this soil stand the possibility of accumulating nickel to a level that it can be dangerous to man. The change in the factor in both millets and sorghum with distance suggests that $\mathrm{pH}$ must have played a strong influence on the metal mobility. Metal contamination is often accompanied by high soil acidity [40]. High acidity has been known to increase metal solubility and mobility [41, 42]. It is likely that increased solubility of 
nickel led to its increased availability and plant uptake, which may accentuate its toxicity.

\subsection{Cobalt in Crop Plants}

Normal plant content of cobalt is $0.2 \mu \mathrm{gg}^{-1}$ [30], however, millet and sorghum analysed from this study area recorded $11.34 \mathrm{gkg}^{-1}$ and $50.90 \mathrm{gkg}^{-1}$ with wide ranges of $2.01-$ $79.86 \mathrm{gkg}^{-1}$ and $2.00-139.61 \mathrm{gkg}^{-1}$ respectively (Table 3). These values are higher than the normal average as such it calls for concern. The concentration factors (Tables 4 and 5) showed that despite the high metal levels in plant crops, there is between $60-90 \%$ still unabsorbed in the soil. The likelihood of Cobalt going into the food chain is high; moreover, it has been classified among highly toxic and relatively accessible elements.

\subsection{Effect of pH on Plant available metals}

The mean soil $\mathrm{pH}$ was found to be $6.76 \pm 0.86$ with a wide range of 4.7-9.84. This shows that the $\mathrm{pH}$ is slightly acidic even though some samples were strongly acidic. The observed $\mathrm{pH}$ is similar to those earlier reported for Savanna soils [43]. Young [44] has reported earlier that most savanna soils are acidic. The $\mathrm{pH}$ values suggest that a wide variety of crops can be grown on the soils. Soil acidity is caused by the removal of basic elements through leaching and crop uptake, organic matter decomposition, acid rain, nitrification of ammonium nitrogen, and by natural soil forming processes [45]. Cement factory emissions when they settle on soil could alter soil $\mathrm{pH}$. In another work around a cement factory in turkey, dust emission was reported to have a $\mathrm{pH}$ of $6.5-8.6$ [46]. This is similar to the $\mathrm{pH}$ range obtained in this work. The acidic $\mathrm{pH}$ values obtained here may have been due to the partial neutralization of the soil by high acidic gas emissions that may have been produced at the plant despite the alkaline cement dust. This was observed by Aslan and Boybay [46] in a work they did in the vicinity of a cement factory. This notwithstanding, the $\mathrm{pH}$ decreases with distance away from the factory, while the factory fence soil recorded slight alkalinity (Table II).

The fate and transport of a metal in soil depends significantly on the chemical form and speciation of the metal [47]. The mobility of metals may be hindered by reactions that cause metals to be absorbed or precipitated or chemistry that tends to keep metals associated with the solid phase and prevents them from dissolving. These mechanisms can retard the movement of metals and also provide a long term source of metal contaminants [48]. Metals undergo similar reactions but, the extent and nature of these reactions vary under particular conditions. The degree of sorption of several metal cations and anions onto iron oxide has been shown to be a function of $\mathrm{pH}$ for a particular electrolyte composition [49].

Micronutrient cations are mostly soluble and available under acidic conditions. In fact, under acid conditions the concentration of one or more of these elements often is sufficiently high to be toxic to common plants. Low $\mathrm{pH}$ increases metal availability since the hydrogen ion has a higher affinity for negative charge on the colloids, thus competing with the metal ions for these sites thereby releasing the metal. The metals become less available as the soil becomes alkaline. Increasing soil acidity induces loss of exchangeable base cations ( $\mathrm{K}, \mathrm{Mg}$ and $\mathrm{Ca}$ ) [52]. The relationships between the ratios of acid extractable crop metal to soil metal and soil $\mathrm{pH}$ $\left(1: 1 \mathrm{H}_{2} \mathrm{O}\right)$ is given in Figs $9-20$. The relationship was obtained by plotting the concentration factors against $\mathrm{pH}$ for all the metals hence, the influence of $\mathrm{pH}$ on the available metals is very glaring suggesting decreasing ratios of crop to soil metals with increasing $\mathrm{pH}$.

In millets, the metals were mostly absorbed at $\mathrm{pH}<6.5$ with the exception of copper (Figs $1-6$ ). The absorption of the metals at this $\mathrm{pH}$ decreases in the order $\mathrm{Ni}>\mathrm{Zn}>\mathrm{Co}>\mathrm{Fe}>\mathrm{Mn}>\mathrm{Cu}$. At $\mathrm{pH}$ above 6.7, the absorption seems to rise steadily for $\mathrm{Fe}$ and $\mathrm{Cu}$ while for $\mathrm{Zn}$ the absorption decreases with increasing $\mathrm{pH}$ from slightly below $\mathrm{pH}$ 6.5. The affinity of $\mathrm{Cu}$ for humates increases as $\mathrm{pH}$ increases [51]. Copper mobility is decreased by Sorption to mineral surfaces. $\mathrm{Cu}^{2+}$ sorbs strongly to mineral surfaces over a wide range of $\mathrm{pH}$ values [52]. Zinc is one of the most mobile heavy metals in surface and ground waters because it is present as soluble compounds at neutral and acidic $\mathrm{pH}$ values. At higher $\mathrm{pH}$ values, zinc can form carbonate and hydroxide complexes which control precipitates under reducing conditions and in highly polluted systems when it is present at very high concentrations, and may co-precipitate with hydrous oxides of iron or manganese [27]. Sorption of zinc increases as $\mathrm{pH}$ increases and salinity decreases [51]. It has been reported that in calcareous soil of $\mathrm{pH}$ above 8.2 , increasing $\mathrm{CO}_{2}$ increased carbonate ions, depressed $\mathrm{Ca}^{2+}$ activity and allowed $\mathrm{Zn}^{2+}$ to be held by chelating agent $[53,54]$. Norvell observed that zinc concentrations are relatively high in acidic soil solution and $\mathrm{Zn}^{2+}$ competes very effectively with $\mathrm{Al}^{3+}$ and $\mathrm{Fe}^{3+}$ for chelating agents but at $\mathrm{pH} 7$ the concentration of $\mathrm{Zn}^{2+}$ is much lower and it competes less effectively with $\mathrm{Ca}^{2+}$. Zinc has been found to become mobile below $\mathrm{pH} 6$ and $\mathrm{pH} 5$ respectively [55] and decreased soil $\mathrm{pH}$ causes shift from organically complexed forms of metals to the free ionic form [56].

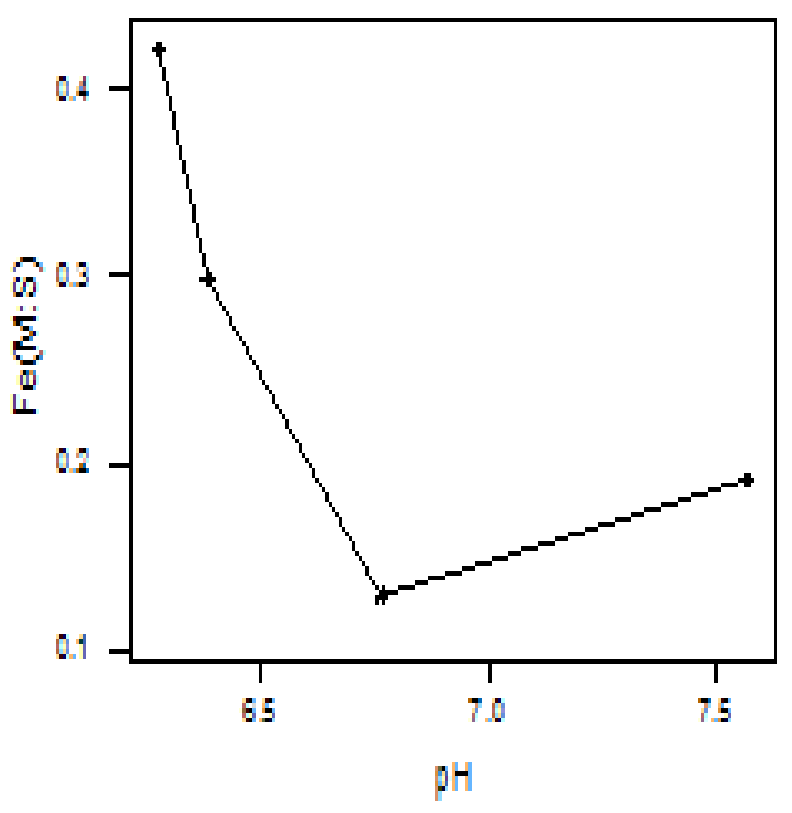


Fig. 1: Relationship of millet/soil iron ratios and soil pH (water/soil, 1:1)

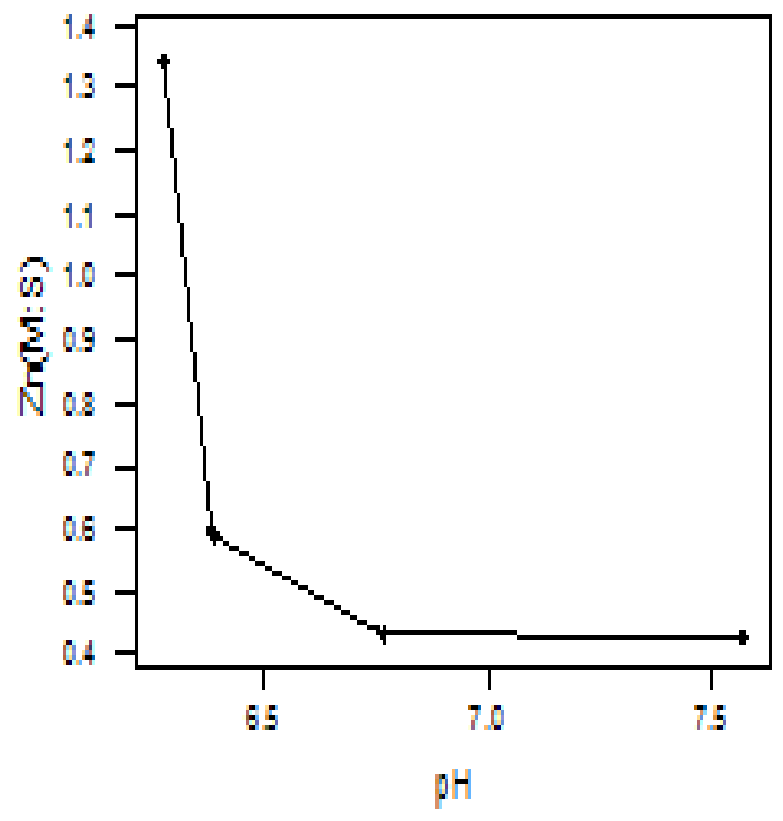

Fig. 2: Relationship of millet/soil zinc ratios and soil pH (water/soil, 1:1)

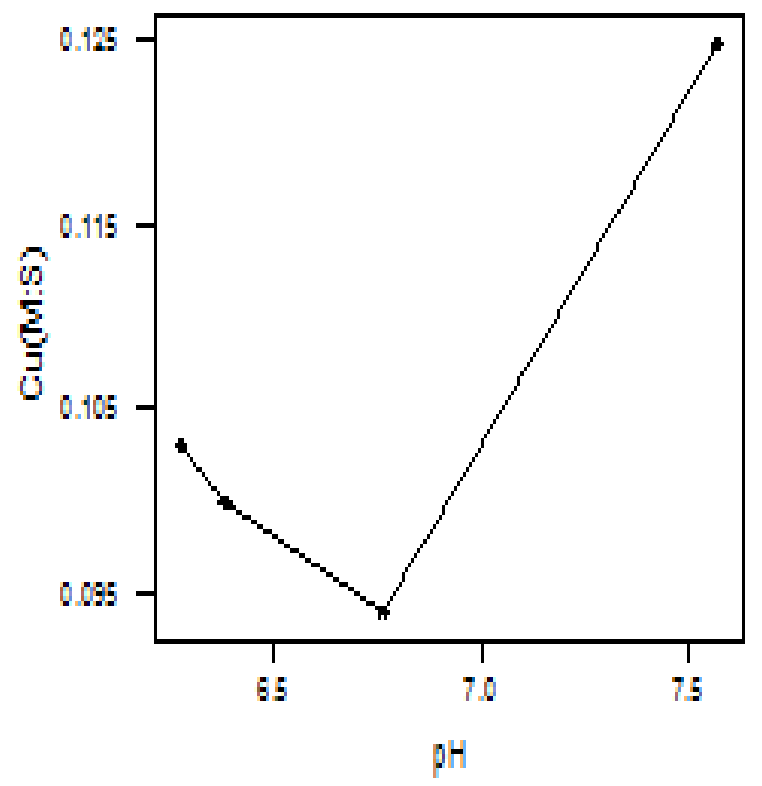

Fig. 3: Relationship of millet/soil copper ratios and soil $\mathrm{pH}$ (water/soil, 1:1)

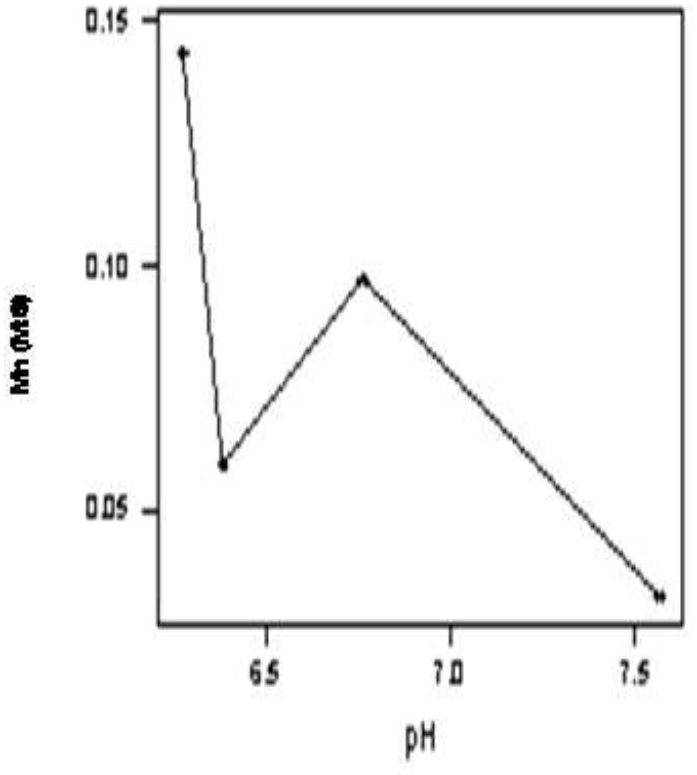

Fig 4. Relationship of Millet/Soil manganese Ratios

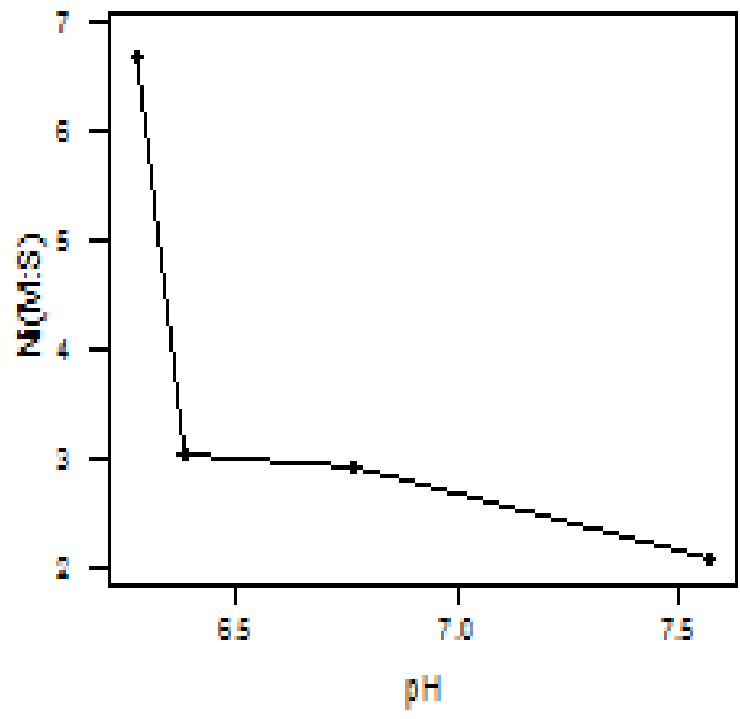

Fig. 5: Relationship of millet/soil nickel ratios and soil $\mathrm{pH}$ (water/soil, 1:1) 


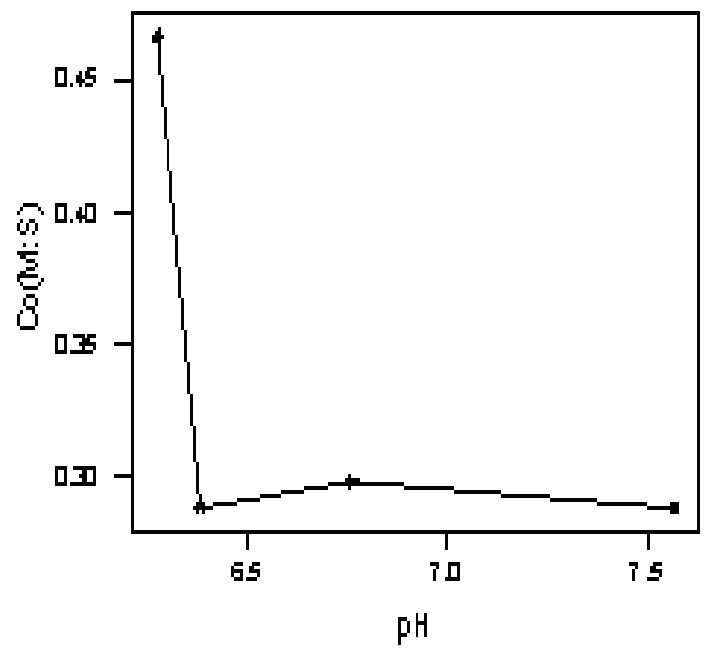

Fig. 6 Relationship of millet/soil cobalt ratios and soil pH (water, 1:1)

The Sorghum and soil metal levels do not follow the same pattern for all the metals considered. The Sorghum metal/soil metal ratio plots against $\mathrm{pH}$ (Figs 7-12) show higher ratios at low $\mathrm{pH}$ for all the metals. At $\mathrm{pH}$ less than 6.3 cobalt records its highest ratio which decreases as the $\mathrm{pH}$ increases. The trend is such that $\mathrm{Fe}, \mathrm{Zn}, \mathrm{Cu}, \mathrm{Mn}$ and $\mathrm{Ni}$ Sorghum/soil ratios rise steadily to their highest concentrations above $\mathrm{pH} 6.3$, but fall as the $\mathrm{pH}$ increases beyond this $\mathrm{pH}$. Sorghum seems to concentrate maximum metals at $\mathrm{pH}$ a little below 6.5 with the exception of $\mathrm{Cu}$. These indicate that availability of metals to plants is critical at $\mathrm{pH} 6-6.5$. At $\mathrm{pH}$ above 6.5, metal availability is decreased. It has been noted that soil acidification is known to increase the solubility and mobility of metals $[41,42]$. It is likely that increased solubility of metal leads to increased availability and plant uptake thus accentuating metal toxicity [57]. The absorption of the metals by sorghum decreases in the order $\mathrm{Zn}>\mathrm{Ni}>\mathrm{Fe}>\mathrm{Co}>\mathrm{Mn}>\mathrm{Cu}$. This order indicates that sorghum shows more preference for $\mathrm{Zn}$ than $\mathrm{Ni}$ as compared to millet, which shows more preference for Ni than $\mathrm{Zn}$.

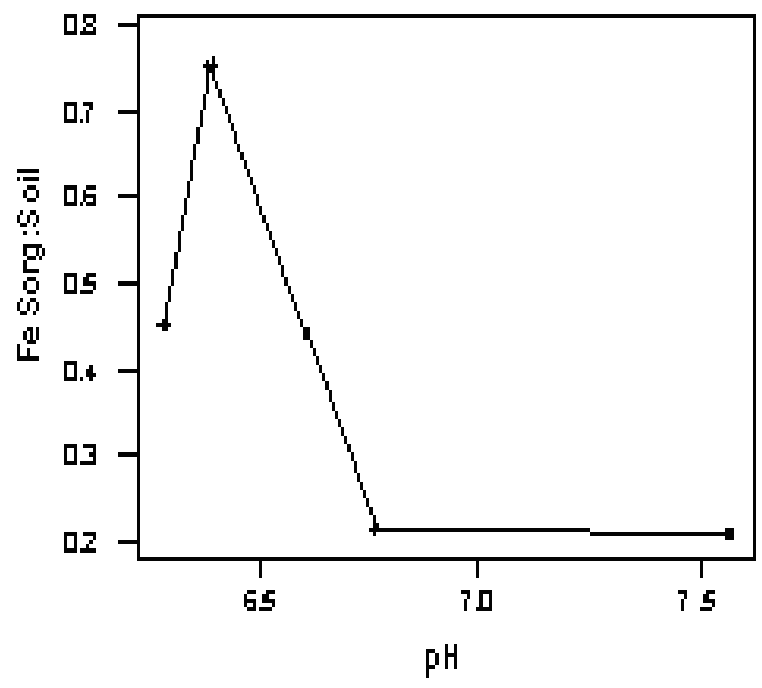

Fig. 7: Relationship of sorghum/soil iron ratios and soil pH (water/soil, 1:1)

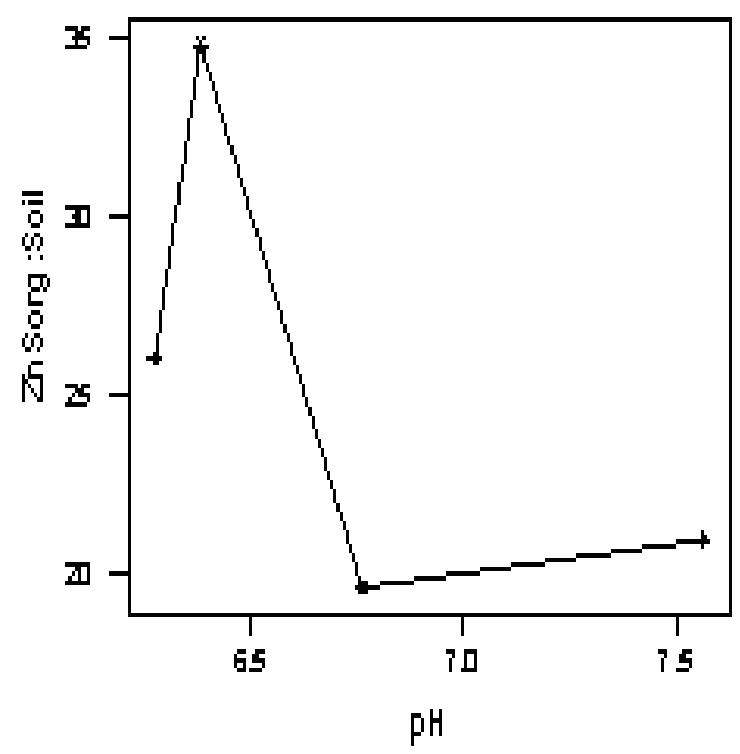

Fig. 8: Relationship of sorghum/soil zinc ratios and soil pH (water/soil, 1:1) 


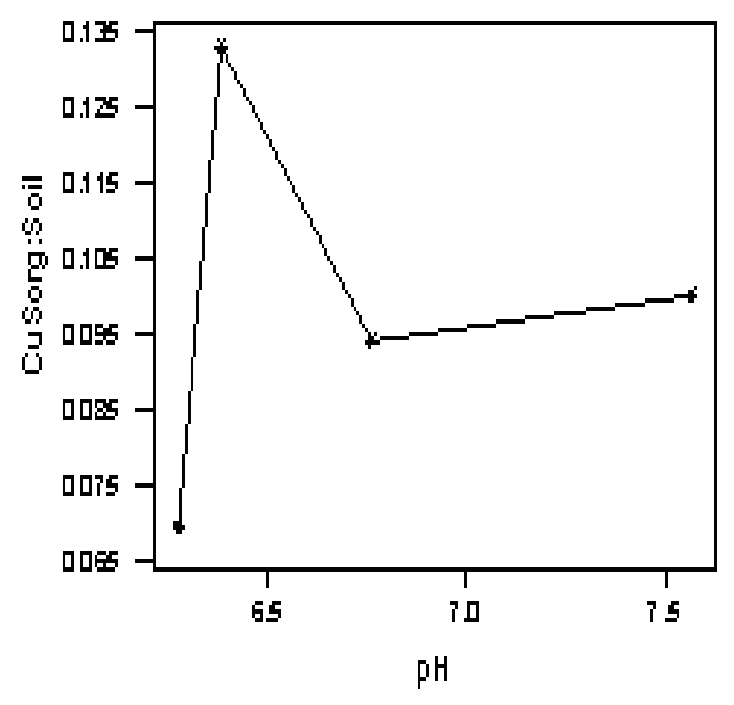

Fig. 9: Relationship of sorghum/soil copper ratios and soil pH (water/soil, 1:1)

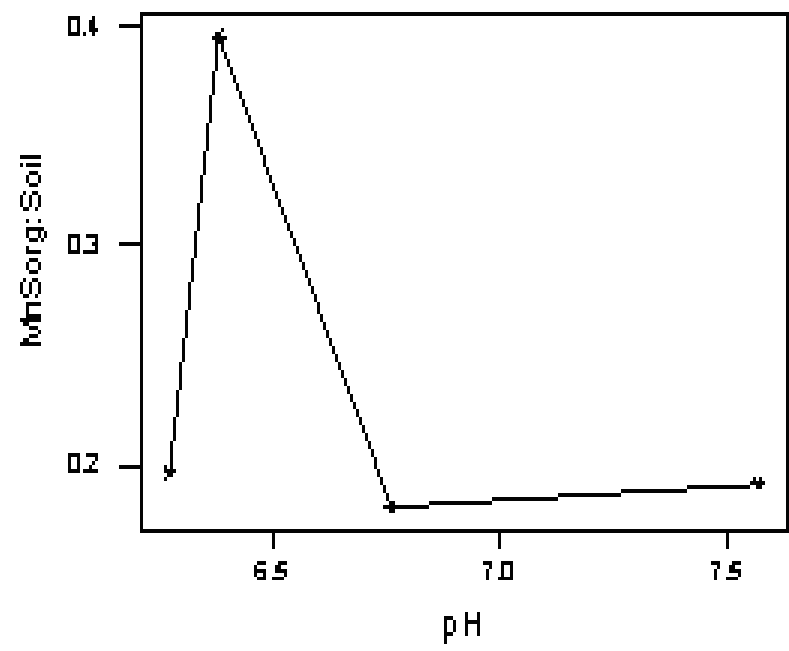

Fig. 10: Relationship of sorghum/soil manganese ratios and soil $\quad$ pH (water/soil, 1:1)

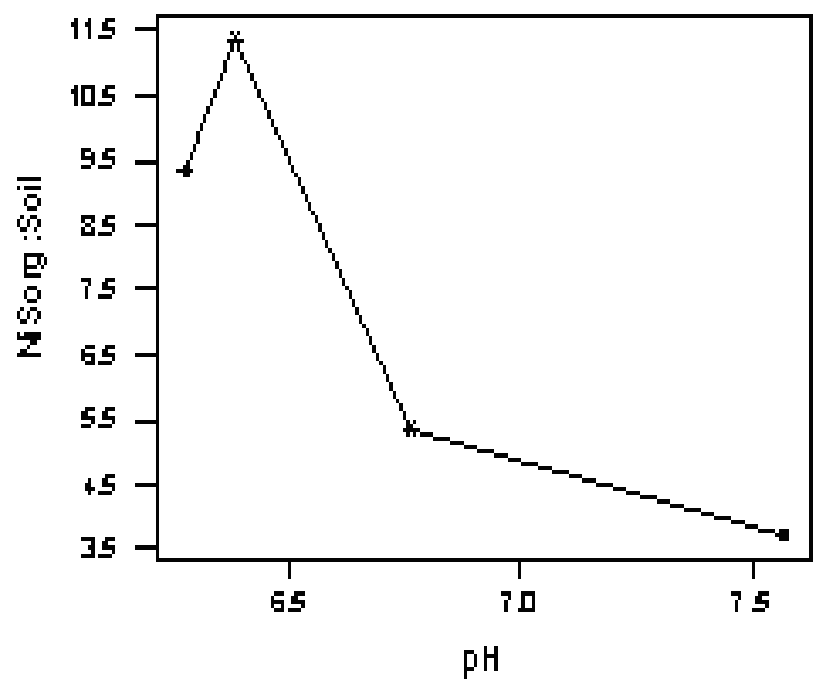

Fig. 11: Relationship of sorghum/soil nickel ratios and soil pH (water/soil, 1:1)

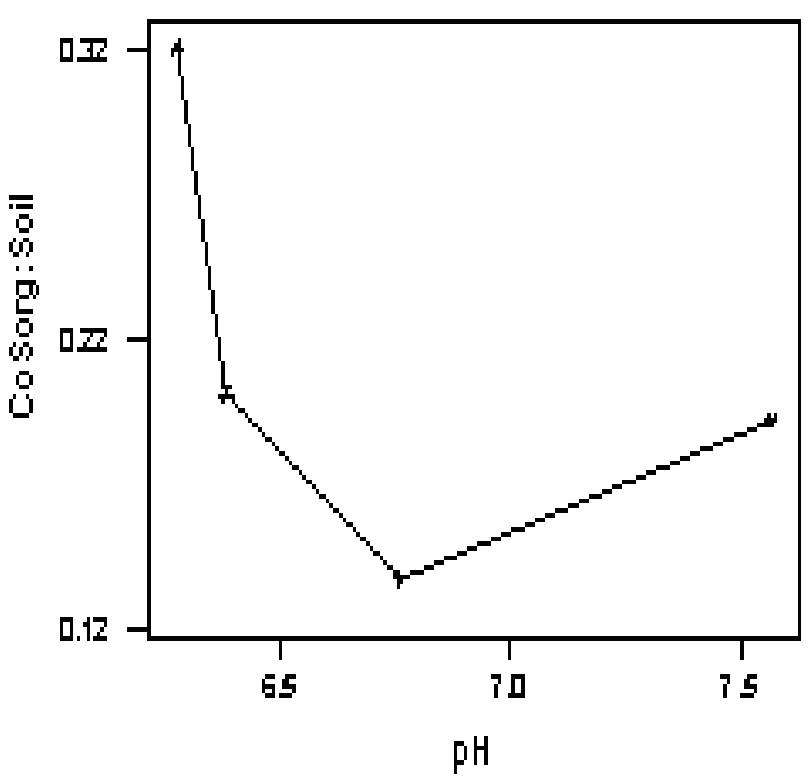

Fig.12: Relationship of sorghum/soil cobalt ratios and soil pH (water, 1:1)

\section{CONCLUSION}

Cement dust is an environmental hazard since it affects soil properties, plants, man and animals within the vicinity of its deposition. The deposition of cement dust over a long period of time may change soil $\mathrm{pH}$ and adds to soil trace metals some of which are toxic to humans, animals and vegetation. $\mathrm{Zn}, \mathrm{Ni}$, and $\mathrm{Mn}$, are heavy metals that were found in the environment above their background levels around the cement factory. Their presence in the environment may pose a serious potential 
health hazard to the communities scattered around the factory. This can be so when the extractable content of the metals are used as indicators of the quantity of the metals available to plants. To this end there may be need to mitigate the likely effects by planting metal accumulating plants around the factory so as to remove metals from the environment.

\subsection{REFERENCES}

1. Hirano, T., Kiyota, M. T. and Aiga, I., 1995. Physical effects of dust on leaf physiology of Cucumber and kidney bean plants. J. Environ Poll. 89 (3); 255 261.

2. Wuana, R. A. and Okieimen, F. E., 2011. Heavy Metals in contaminated soils: A Review of sources, chemistry, risks and best available strategies for remediation. International scholarly Research Network; Ecology, vol. 2011

3. Farmer, .A. M., 1993. The effects of Dust on vegetation - A Review. Environ poll. 79, 63 - 75.

4. Huong, N. T., 2007. Cement Production. www.inive.org/members-area/medias (Accessed 30th June, 2007)

5. Tijani, A. A., Ajobo, O. and Akinola, A. A., 2005. Cement production externalities and profitability of crops enterprises in two local government areas of Ogun state. J. Soc. Sci. 11, $43-48$.

6. Oyodele, A. J., Aina, P. O., Oluwale, F. and Asubiojo P. O., 1990. Preliminary assessment of pollution effects of cement dust on soil and biomass production. A paper presented at the 18th annual conference of the Nigeria soil science society, held at Maiduguri, Nigeria.

7. Kloseiko, J. and Tilk, M., 2006. Influence of cement clinker dust on carbohydrates in needles of scots pine shortly after the application. Proc. Estonian Acad. Sci. Biol. Ecol. 55(2), 149-159.

8. Parn, H., 2006. Radial growth of conifers in regions of different cement dust loads. Proc.Estonian Acad. Sci. Biol. Ecol., 55(2), 108-122.

9. Abou Seeda, M. Z.,Zaghoul, A. M. and Abdel-Gelil, A., 2005. The role of element dust in chemical remediation of sludge treated soil. Ass. Univ. Bull. Environ. Res. 8(2), 89-106

10. Milford, J. B. and Davidson, C. I., 1985. The sizes of particulate trace elements in the atmosphere - A review. J. Air poll. Contr. Assoc. 35, 124 - 126.

11. Omar, J. M. and Jasim, F., 1990. Some observations on the use of electro thermal atomic absorption spectrophotometry for the determination of chromium and copper in portland cement. Microchemistry journal, 41(3), 348 - 355.

12. Andrej, J., 1987. Bees and their products as indicators of environmental pollution. Med. Weter. 43 (6), 353 - 356.

13. Kara, A., Cetin, S. C., Turgay, O. C., and Kizilkaya, R., 2010. Effects of heavy metals on soil enzyme activities. In Sherameti, I. and Varma, A. (ed.) Soil heavy metals, soil biology. Heidelberg 19, Pp237 265

14. Kabata-Pendias, A. and Pendias, H., 2001. Trace metals in soils and plants, $2^{\text {nd }}$ edition CRC Press, Boca Raton, Fla, USA
15. Pierzynski, G. M., Sims, J. T. and Vance, G. F., 2000. Soil and environmental Quality, $2^{\text {nd }}$ edition. CRC Press, London, UK.

16. D'Amore, J. J., Al-Abed, S. R., Scheckel, K. G., and Ryan, J. A., 2005. Methods for speciation of metals in soils: A Review, Journal of environmental quality, 34, (5) pp1707 - 1745.

17. Garrido, S., Campo, G. M. D., Esteller, M. V., Vaca, R., and Lugo, J., 2002. Heavy metals in soils treated with sewage sludge composting; their effect on yield and uptake of broad bean seeds (vicia faba). Water, Air and soil pollution, 166, 303-319

18. Rascio, N. and Izzo F. N., 2011. Heavy metal hyperaccumulating plants: How and why do they do it? And what make them so interesting? Plant Sci. 180, 169-181

19. Wong, J. W. C. and Selvam, A., 2006. Speciation of heavy metals during co-composting of sewage sludge with lime, Chemosphere, 63, 980-986

20. Jordao, C. P., Nascentes, C. C., Cecon, P. R., Fontes, R. L. F. and Pereira, J. L., 2006. Heavy metal availability in soil amended with composted urban solid wastes. Environmental monitoring and assessment, 112, 309-326

21. Khan, S., Cao, Q., Zheng, Y. M., Huang, Y. Z. and Zhu, Y. G., 2008. Health risk of heavy metals in contaminated soils and food crops irrigated with waste water in Beijing, China. Environmental pollution, 152, 686-692

22. Singh, J. and Kalamdhad, A. S., 2011. Effects of heavy metals on soil, plants, human health and aquatic life. International Journal of Research in Chemistry and Environment, 1, 15-21

23. Speira, T. W., Kettlesb, H. A., Percivac, H. J. and Parshotam, A., 1999. Is soil acidification the cause of biochemical responses when soils are amended with heavy metal salts? Soil Biology and Biochemistry, 31, 1953-1961

24. Maslin, P. and Maier, R. M., 2000. Rhamnolipidenhanced mineralization of phenanthrene in organicmetal co-contaminated soils. Bioremediation Journal, 4 (4), 295-308

25. Nigeria Stock Exchange, NSE, 2004. Investors guide: The cement industry in Nigeria. http://www.pangaeapartners.com/nigjuly/.htm (accessed, April, 2004).

26. Smith, S. R., 1994. Effect of soil pH on availability to crops of metals in sewage sludge treated soils. 1 . Nickel, copper and zinc uptake and toxicity to ryegrass. Environ. Poll. 85, 321 - 327

27. Juste, C. and Tauzin, J., 1992. Comparison de la biodisponibilite $\mathrm{du}$ cadmium contenu dans differentes matieres fertilisantes. C. R. Acad. Agric.Fr. 79, 71 - 79.

28. Voutsa, D., Grimanis, A. and Samara, C, 1996. Trace elements in vegetables grown in an industrial area in relation to soil and air particulate matters. Environ. Poll. 94, 325 - 335.

29. Luo, Y. and Rimmer, D. L., 1995. Zinc - copper interactions affecting plant growth on a metal contaminated soil. Environ. Poll. 88, 79 - 83. 
30. Markert, B., 1994. Plants as bioindicators - potential advantages and problems. In: Andriano, D. C., Chen. Z. S., and Yang, S. S. (eds.) Biochemistry of trace elements. Science and Technology letters, Northwood, New York. Pp 601 - 613.

31. Kabata - pendias, A. and Pendias, H., 1984. Trace elements in soil and plants. CRC press Boca Raton USA

32. Huchabee, J. W., Sanz-Diaz, F., Janzen, S. A and Solomon, J., 1983. Distribution of mercury in vegetation at Almaden, Spain. Environ. Poll. 30, 211 $-224$.

33. Hovmand, M. F., Tjell, J. C. and Mosbaek, H., 1983. Plant uptake of airborne cadmium. Environ. Poll. 30, $27-38$.

34. Alloway, B. J., 1990. Heavy metals in soils. Black Well, London.

35. McGrath, S. P., 1989. Crop yield and composition. In: de Haan, F. A. M. et al (eds.). Commission of the European communities DGXIIE XII/523/89.

36. Sanchez - Camazaro, M., Sanchez - martin, M. J. and Lorenzo, L. F., 1994. Lead and cadmium in soils and vegetables from urban gardens of Salamanca (spain). Sci Total Environ. 146/147, 163 - 168.

37. Larsen, E. H., Moseholm, L. and Nielson, M. M., 1992. Atmospheric deposition of trace elements around point sources and human health risk assessment. II. Uptake of arsenic and chromium by vegetables grown near a wood presentation factory. Sci. Total Environ. 126, 263 - 275.

38. Harrison, R. M. and Chirgawi, M. B., 1989. The assessment of air and soil as contributors of some trace metals to vegetable plants I. Use of a filtered air growth carbinet. Sci. Total Environ. 83, 13 - 34.

39. Feigin, A., Ravina, I. and Shalhevet, J., 1991. Irrigation with treated sewage effluent. Springer verlag, Berlin.

40. Temple, P. J. and Bessessar, S., 1981. Uptake and toxicity of nickel and other metals in crops grown on soil contaminated by nickel refinery. J. Plant Nutr. 3(103), 473 - 482.

41. Lebersli, E. M. and Steinnes, E., 1987. Metal uptake in plant from a birch forest area near copper smelter in Norway. Water, Air, Soil, Poll. 37, 25 - 39.

42. Tyler, G., 1978. Leaching rates of heavy metal ions in forest soils. Water, Air, Soil Poll. 9, 137 - 148.

43. Lombin, G., 1983. Evaluating the micronutrient fertility of Nigeria's semi-arid savanna soils: Zinc. Soil Science, 136, 42 - 47.

44. Young, A., 1976. Tropical soils and soil survey, Cambridge Pp486

45. Mcfarland, M. L., Haby, V. A., Redmon, L. A. and Bade, D. H., 2001 - 2005. Managing soil acidity. Texas Agricultural and experiment station (TAES), SCS 2001 - 2005. http://www.soilcrop.tamu.edu.

46. Arslan, M. and Boybay, M., 1990. A study on the characterization of dust fall. Atmosph. Environ. 24A, $2667-2671$.

47. Allen, J. P. and Torres, I. G., 1991. Physical separation Techniques for contaminated sediments. In: Li, N. N. (ed.). Recent developments in separation sciences. CRC press, West Palm Beach FL Vol. V.

48. N R C, 1994. Alternatives for ground water clean up. National Research Council, National Academy Press, Washington DC.

49. Kinniburgh, D. G., Jackson, M. L. and Syers, J. K., 1976. Adsorption of Alkaline earth, transition and heavy metal cations by hydrous oxide gels of iron and aluminum. Soil Sci. Soc. Amer. J. 40, 796 - 799.

50. Ulrich, B., 1983. Soil acidity and its relation to acid deposition. In, Ulrich, B. and Pankrath, J. (eds.). Effects of accumulation of air pollutants in forest ecosystems. Reidel Publ. Co. Dordrecht. Pp 127 146.

51. Evanko, C. R. and Dzombak, D. A., 1997. Remediation of metals contaminated soils and ground water. Technology Evaluation Report GWRTAC E - series TE. 97-01 Pp 1 - 13.

52. Dzombak, D. A. and Morel, F. .M. .M., 1990. Surface complexation modeling: Hydrous ferric oxide. John Wiley and sons New York.

53. Lindsay, W. L., 1972. Inorganic phase equilibria of micronutrient in soils. In: Mortvedt, J. J. Giordano, P. M. and Lindsay, W. L. (eds.). Micronutrients in Agriculture SSSA Madison, Wisconsin USA. Pp 41 $-58$.

54. Norvell, W. A., 1972. Equilibria of metal chelates in soil solution. In: Mortvedt, J. J., Giordano, P. M. and Lindsay, W. L. (eds.). Micronutrients in Agriculture SSSA Madison, Wisconsin USA. Pp 115 - 138.

55. Scokart, P. O., Verdinne, K. M. and Borger, R. D., 1983. Mobility of heavy metals in polluted soils near zinc smelters. Water, Air, Soil Poll. 20, 451 - 463.

56. Emmerich, W. E., Lund, L. J., Page, A. L. and Chang, A. C., 1982. Solid phase forms of heavy metals in sewage sludge - treated soil. J. Environ. Qual. 11, 178 - 181.

57. Watmough, S. A. and Dickson, N. M., 1995. Dispersal and mobility of heavy metals in relation to tree survival in an aerially contaminated woodland soil. Environ. Poll. 90, 135 - 142. 